UDK 821.111-313.2.09Morris W.:929Hudson W. H.

\title{
DREAMERS IN DIALOGUE: EVOLUTION, SEX AND GENDER IN THE UTOPIAN VISIONS OF WILLIAM MORRIS AND WILLIAM HENRY HUDSON
}

\author{
Caterina Novák
}

\begin{abstract}
:
The aim of this article is to explore the parallels between two late-nineteenth-century utopias, William Henry Hudson's A Crystal Age (1882) and William Morris's News from Nowhere (1891). It aims to explore how these two works respond to the transition from a kinetic to a static conception of utopia that - under pressure from evolutionary and feminist discourses - took place during the period. Particular focus lies on the way in which this is negotiated through the depiction of evolution, sexuality, and gender roles in the respective novels, and how the depiction of these 'disruptive' elements may work as a means of ensuring the reader's active engagement in political, intellectual and emotional terms.
\end{abstract}

Keywords: William Henry Hudson: A Crystal Age, William Morris: News from Nowhere, treatment of evolution, treatment of sexuality, utopian fiction

The history of utopia - in the sense of man's dream of a perfect society may well go back to the origins of mankind itself. As a literary phenomenon, too, its history extends much farther back than to the seventeenth-century work which lent its name to the genre. While different scholars have identified different periods as the heyday of the literary utopia, there seems to be near-universal agreement that utopian fiction, in decline for most of the eighteenth and nineteenth centuries, rose to prominence again towards the close of the Victorian period (Kumar 35). Critics have attributed this upsurge of interest in utopian fiction partly to a strong belief in the ultimate perfectability of human society that owed much to nineteenth-century notions of technological progress and theories of (social) evolution of the kind best described as “not 'Darwinian' but 'Darwinistic' (or, crudely, erroneous)" (P. Morton, Science 9). In part, however, literary utopias also served a consolatory function, offering escape from the bleak realities of the present and the realisation that utopian perfection - if it could be attained at all - would be achieved only in the remote future. This holds true especially within a Socialist context, as the likelihood of a proletarian revolution diminished in the face of the increasing internal fragmentation of the movement (Kumar 67; Kinna 744). 
Both in form and conception, these late Victorian utopias differ significantly from their literary precursors. Until the last third of the nineteenth century, most utopias had followed the traditional pattern in which a traveller to distant lands accidentally discovers an ideally perfect society flourishing in some remote region of the globe, in a state of isolation from its neighbours and uncontaminated by intercourse with the rest of the world (Kumar 23). By the 1870s, however, imperialist expansion had deprived writers of blank spaces on the map (A.L. Morton 192). At the same time, the incorporation of notions such as progress as an inherent function of human history, biological evolution as a way towards the perfection of the human race, and a strong belief in technological advancement introduced a crucial new element into utopian fiction: time. By the late nineteenth century, the device of a narrator who goes to sleep in the present, only to find himself, upon his awakening, in some ideally perfect society several hundred years in the future had become a standard feature of literary utopias (Kumar 38f.), popularised not least by two of the most influential contemporary examples of the genre, Edward Bellamy's Looking Backward (1885) and William Morris's News from Nowhere (1891).

As a consequence of these developments, the traditionally static conception of utopia as a state of perfection that, once reached, needs only to be maintained, gave way to the realisation that, in the words of H.G. Wells, "the utopia of a modern dreamer must needs differ in one fundamental aspect from the Nowheres and Utopias men planned before Darwin quickened the thought of the world [...] the Modern Utopia must not be static but kinetic, must shape not as a permanent state but as a hopeful stage, leading to a long ascent of stages" (Wells 11). ${ }^{1}$

Moreover, Darwinism had inevitably introduced the issue of human sexuality into utopia, either in the form of greater sexual permissiveness to facilitate natural selection, or in the shape of strictly regulated policies of procreation along Malthusian and eugenicist lines (Sedlak 221). Predictably, treatment of this subject did not remain on a purely theoretical footing, leading to the inclusion of a romantic element into utopian fiction that is notably absent from earlier works, and that gave female characters a more prominent position, typically in the twin functions of love interest and guiding figure for the male narrator (Baccolini 701). At the same time, the ever-growing pressure exerted by the feminist movement was such that by the end of the Victorian era, "sexual equality [...] [had become] a central issue in utopia" (Baruch 34). Nonetheless, many authors merely "prospected solutions and reforms which were nonetheless never revolutionary, but often ambiguous", and the roles of wife and mother almost invariably remained the central ones envisaged for women (Baccolini 701). If the greater prominence afforded to female characters did nothing to transform the "historically misogynistic genre of utopia" (Lewes 23), however, it nonetheless was not without its impact, adding another element to disrupt the static nature of traditional utopian societies (Baccolini 701; Domenicelli 367ff.).

This article sets out to explore how this network of disruptive influences is negotiated in two utopian novels published during the last decades of the nineteenth century, William Morris's Socialist classic News from Nowhere, and William Henry Hudson's A Crystal Age. It goes without saying that Morris' treatment of women in News from Nowhere has already received a significant amount of attention, as have most

${ }^{1}$ cf. also Partington non pag. and Pinkney 51. 
other aspects of the novel, and this article can only provide a very selective overview of those arguments which are germane to the topic at hand. A Crystal Age, in contrast, has attracted far less notice, both at the time of its publication and in recent decades. This relative critical neglect is only partly attributable to the novel's lack of literary merit (indeed, the main point on which it incurs criticism - i.e. its flat characterisation and meagre plot - is one that it shares with many utopian novels, not least Morris' own work ${ }^{2}$ ). In part, it may well be due to the fact that it differs markedly from the remainder of Hudson's extensive oeuvre, and the tendency on the part of his biographers to concentrate on his work as a naturalist and travel writer. An important reason also must be sought in the utter improbability of Hudson's utopian vision, and its remoteness from everyday experience. As A.L. Morton remarks in his classic The English Utopia, "[t] he most striking thing, perhaps, about A Crystal Age is its complete lack of relation to anything in the existing world, except by antipathy" (206).

First published in 1887, A Crystal Age is highly unusual, if not unique, among utopian romances of the period for two important reasons. Firstly, it envisages a period in the remote future when evolutionary processes have done away with the human sex drive, so that the social organisation of the Crystallites ${ }^{3}$ resembles nothing so much as that of the beehive, with a single married couple presiding over a large group of entirely asexual workers. ${ }^{4}$ Idiosyncratic as it may seem to modern readers, Hudson's vision of a sexless society is not simply an expression of the author's individual tastes. By the fin de siècle, a number of theorists had begun to voice the opinion that the abnormal development of human sexual instincts had turned them into a disease, while more extreme feminists explicitly stated their hopes that social evolution would eventually lead to an entirely sexless state (Fernando 23). Hudson's novel, it would seem, draws on these feminist fantasies; on the other hand, however, it also reflects the attitude of many contemporaries who, despite their dissatisfaction with the status quo, found this alternative "even more depressing than present sexuality" (Fernando 23).

The work is not only unique in its treatment of love and sexuality. The second, and perhaps much more radical, departure from established genre conventions lies in the absence of a clearly defined guiding figure to ease the narrator's entry into utopian society: unaccountably transported several millennia into the future after a fall down a ravine, the young botanist Smith encounters a group of Crystallites, and becomes strongly attracted to a beautiful young woman named Yoletta. While he is hospitably accepted into her father's household, neither she nor any other character takes it upon themselves to explain to Smith the intricacies of life in the Crystal Age. In addition, both the Crystallites' readiness to take offence at Smith's inadvertent transgressions against established codes of conduct, and the narrator's reluctance to confess his ignorance for fear of lowering himself in his beloved's estimation, make for a series of misunderstandings that is frustrating for narrator and reader alike.

\footnotetext{
${ }^{2} \mathrm{cf}$. for instance Willmer xxxvi.

${ }^{3}$ I have borrowed the term "Crystallites" and the related adjective from Battaglia.

${ }^{4}$ Although indignantly refuted by the author, it seems probable that Hudson drew on two papers by the biologist and neo-Darwinian sociologist Benjamin Kidd on the behaviour of bees (from which Kidd then drew conclusions about human society) for his idea, which is unparalleled in the history of utopian fiction (P. Morton, "Tracing" 61ff.; P. Morton, Science 80; for the analogy of the beehive, cf. also Battaglia 145; Suvin 33). An important difference, however, lies in the fact that there are no drones.
} 
While hardly gifted with overmuch intelligence or intuition, Smith can only in part be blamed for his blunders, given the amount of change that has taken place: the population of England has decreased significantly; towns and all signs of industrialisation have disappeared, and people live in isolated, largely self-sufficient households. In many instances, the society in which the narrator finds himself is revealed as the exact opposite of Victorian England: most of the things valued "in that feverish, full age" (Hudson 294) have been "consumed to ashes: politics, religions, systems of philosophy, isms and ologies of all descriptions; schools, churches, prisons, poorhouses; stimulants and tobacco; kings and parliaments; cannons [...] and pianos [...] the press, vice, political economy, money and a million things more..." (Hudson 293-4).

Apart from its asexuality and matriarchal organisation (of which more shall be said later on), the most striking feature of Crystallite society is the importance each family attaches to the house in which it lives: as A.L. Morton points out, it is almost as if the people existed to serve the house, rather than the house to shelter the people (207). The house is regarded as a symbol of the world, and the act of decorating it as a conscious emulation of God's act of creation and thus a religious duty. Like the world itself, houses are believed to have neither beginning nor end, and to speak of building or pulling down a house is regarded as blasphemy. Consequently, decorative arts and knowledge pertaining to the beautification of the house are held in high esteem, while all other branches of science (especially natural science) are abhorred as having caused the downfall of nineteenth-century civilisation.

Each house is presided over by a single married couple, who are nominally (and in most cases also biologically) the Mother and Father of all other members of the household. The parents' word is considered law, and the couple - especially the "august Mother of the House, from whose sacred womb ever comes to it life and love and joy" (Hudson 88) - are treated with the utmost veneration by their children. Despite the Malthusian propensities of the Crystallites, who see overpopulation as the root of most of the evils of the social order they have left behind, a large number of children is regarded as eminently desirable in a Mother: the amount of love and worship she receives during her lifetime increases in proportion, as does her chance of being remembered after death. While undeniably problematic in regard to women's roles in Crystallite society (a point which will be discussed at greater length below), the system ostensibly abolishes the patriarchal power structure typical of Victorian families. If there is a gender hierarchy, it is the female who is, in theory at least, accorded the dominant role, since the main function of marriage, i.e. the begetting of children, is her task.

Towards the ends of their lives, the parents choose their successors, who then undergo a period of initiation into the secrets of procreation prior to becoming the new parents of the house. Although it is likely that the parents are aware of individual preferences and take these into account when selecting the new couple, the man and woman involved have no say in the matter and are only informed of their parents' decision after it has been taken. Since the Crystallites are entirely ignorant of the concepts of sexual and/or romantic love, this does not prove a problem to the couple involved, the honour conferred upon them apparently outweighing the lack of freedom in their choice of marriage partner. Throughout the book, the Crystallites' insistence that there exists only one kind of love - i.e. filial and brotherly affection - and their rational attitude towards 
unhappiness ("we seek no other support in all sufferings and calamities but that of reason only" [Hudson 197]) at times makes them appear almost inhuman in comparison with the narrator. The depiction of Smith's unrequited love thus serves a double function: on the one hand, it engages our sympathy for a narrator whom the educated reader is otherwise bound to find somewhat irritating (especially when he confesses his aversion to reading or flaunts his ill-considered opinions on the Woman Question), but who through his ability to love emerges as far more human than the Crystallites.

On the other hand, however, the inclusion of a love interest underlines the inherent ambiguity of Hudson's utopia: while it is certainly difficult, as Peter Morton has argued, to read the novel as an intentional dystopia (Science 75; 80), the importance of authorial intention - questionable in any case - palls when one considers the discomfort the nineteenth-century narrator experiences in a society that has ostensibly achieved perfection, and the strong sense of nostalgia for Victorian England that permeates the text. ${ }^{5}$ Increasingly, Smith moves from enjoyment of life among the Crystallites - "It seemed to me now that I had never really lived before, so sweet was this new life so healthy, and free from care and regret" (Hudson 149) - to despair about their lack of mutual rapport when it comes to his all-consuming passion for Yoletta. The more strongly the reader is moved to sympathise with Smith's plight, the more blurry becomes the distinction between the narrator's viewpoint of Crystallite society, and the more favourable one mapped out for the reader.

In his treatment of the narrator's passion for a woman from the Crystal Age, Hudson acknowledges, but fails to negotiate, the key problems that the inclusion of a romantic element poses for utopian fiction: how to bridge the emotional gap between 'ordinary' humans and the more perfect beings that inhabit utopia? And how to reconcile the possibility of personal unhappiness with utopia's promise of universal happiness? In the beginning of the novel, the narrator is convinced that he and the Crystallites may differ widely in numerous points, "like the widely diverging branches of a tree; but, like the branches, we have a meeting-place, and this is, I fancy, in that part of our nature where our feelings are" (Hudson 32). As it turns out, however, this is precisely the point at which they differ most: in The Crystal Age, both sexual love and intense suffering, grief, and despair can only be experienced by the Mother; they are "the penalty she must pay for her higher state" (Hudson 191). For this reason, she is the only one in the household who can even attempt to understand the narrator's feelings, which even to her "seem unlike [theirs]" (Hudson 190). At the end of the novel, Smith - having become convinced that Yoletta will never come to love him in the same way as he loves her - chances upon a draught which he believes will grant him immunity from his sexual impulses. When he drinks from the bottle, the potion transports him back into the Victorian age. He fades out of the Crystal Age at the very moment that his beloved arrives to tell him that they have been chosen to succeed the present Father and Mother of the house. The book ends with Yoletta's scream when she discovers her lover's motionless body.

\footnotetext{
${ }^{5}$ In the preface to the second edition, however, the author himself admits that his dream of human perfection, which seemed immeasurably remote even at the time of writing, has finally given way to the conviction that an absence of (sexual) competition can only lead to degeneration and decay (viii).
} 
There is no evidence that William Morris had read A Crystal Age when he wrote his much more influential News from Nowhere, commonly assumed to have been intended as a direct response to Edward Bellamy's Looking Backward (e.g. A.L. Morton 198; Willmer xxxv). As A.L. Morton points out, however, it is not implausible that he may have heard of Hudson's work through mutual acquaintances (206). As it is, there are numerous points of contact between the two works, to the extent that A Crystal Age tends to be mentioned - if it is mentioned at all - in connection with Morris' utopia. It is only A.L. Morton, however, who makes a sustained attempt to highlight the similarities between the two novels, coming to the conclusion that "A Crystal Age has certainly features which remind us of News from Nowhere, the socialism, of course, always excluded" (206). ${ }^{6}$ Morton mentions both its conception of utopia as "an epoch of rest" (vide the subtitle of Morris's book), and its depiction of a peaceful, pre-industrial society whose members live in harmony with each other and with nature. In many other respects, too, the Nowhereans resemble the Crystallites: they relish simple, homecooked food; delight in colourful clothing apparently inspired by medieval fashions; are extremely good-looking, healthy, and long-lived; ${ }^{7}$ own little or no personal property; are ignorant of the concepts of buying and selling; place great value on beautiful architecture and house decoration; have abjured technological and scientific advancement; have done away with all forms of institutionalised education, religion, and government; display a marked lack of interest in history; and live in harmony with nature. Moreover, both utopias allow the reader to retrospectively rationalize the narrator's experiences as part of a dream (A.L. Morton 207).

While certainly accurate as far as it goes, Morton's two-page comparison of the two works remains very much on the surface, failing to pinpoint several important parallels: both utopias are similar in that they postulate a cataclysmic event (the Socialist Revolution of 1952 in News from Nowhere, the outbreak of a devastating disease in A Crystal Age) which destroys nineteenth-century civilisation and gives mankind the chance to evolve into a higher state. In both, "childhood and rest are represented as making the ideal condition of man", as Lionel Trilling (158) remarks of News from Nowhere. As such, they both embrace the same paradox: they depict the inhabitants of their respective utopias as the products of evolutionary processes that appear to have taken them not forward, but back to a lower, more child-like state of development. Moreover, they are informed by a sense of nostalgia for an imaginary lost Golden Age that harks back to former historical periods for inspiration. In addition, both utopias feature narrators who can be read as ironic self-portraits of their authors ${ }^{8}$ and who display a keen interest especially in the charms of utopian women; ${ }^{9}$ both works strive (but ultimately fail) to redefine established gender roles; and finally, both utopias enter

\footnotetext{
${ }^{6}$ Not all contemporary readers would have agreed with this point: in his foreword to the 1916 American edition, Clifford Smyth states that "[i]t has been said that A Crystal Age renders a perfect picture of the Socialist state" (xii).

${ }^{7}$ The scene in which Guest discovers the true ages of his companions - whom he has taken to be several decades younger than they actually are - closely resembles the scene when Smith finds out the ages of Yoletta and her family, with the distinction that Morris' estimates are a trifle more credible.

${ }^{8}$ For this point about News from Nowhere, cf. e.g. Willmer xxxv.

${ }^{9}$ For sustained discussion of this aspect of News from Nowhere, cf. Marsh, "News from Nowhere as Erotic Dream".
} 
into the question of the ultimate realisability of their visions through the abortive love relationships between the narrator and a female inhabitant of utopia. When Darko Suvin describes A Crystal Age as "well rendered if ultimately ambiguous and self-defeating" (33), he might as well have been commenting on the many inconsistencies within Morris' News from Nowhere which have given rise to scholarly debate during recent decades. ${ }^{10}$ In contrast to existing scholarship, however, this article compares and contrasts the two works in order to explore how their inconsistencies not only provide important points of contact, but throw light on their respective impact on the reader.

What is most noticeable, in this context, is the prevalence of what might be termed 'Hudsonian' moments in News from Nowhere: scenes in which Morris appears to take up themes from A Crystal Age, and to directly address questions raised by Hudson's vision. One of these is certainly the scene in which the young boatman Dick Hammond (one of William Guest's guides through Nowhere) explains to the narrator how the Nowhereans can "live amidst beauty without any fear of becoming effeminate" (Morris 194). Dick's statement appears somewhat out of context in Morris's novel, and seems to counter a charge that might more justifiably be raised against Crystallite men, whose appearance lacks most of the characteristics traditionally considered masculine:

[...] I was at first puzzled to know whether the party was composed of men or women or both, so much did they resemble each other in height, in their smooth faces, and in the length of their hair. On a closer inspection I noticed the difference of dress of the sexes; also that the men, if not sterner, had faces at all events less mild and soft than the women, and also a slight perceptible down on the upper lip. (Hudson 15)

In News from Nowhere, Morris is careful to stress the 'masculine' credentials of his male characters; in fact, "manly" is among the first adjectives Guest uses of his new-found friend Dick even as he describes his ornate clothing, refined speech and mild manners (Morris 47). Morris capitalises on the one counter-argument Hudson might likewise have emphasised: the greater physical strength and endurance that men develop in the absence of machinery to take over the more strenuous tasks. While Hudson merely draws attention to the physical fitness of Crystallite women - like their Nowherean sisters sensibly clothed rather than "upholstered like armchairs" (Morris 53) and accorded much greater scope for their bodily development - Morris draws on this point to emphasise the 'masculine' credentials of his mild-mannered, art-loving male Nowhereans.

As it is, the issue of gendered identity is the point at which Morris might have learnt most from Hudson's mistakes, given the problematic treatment the issue receives in A Crystal Age. Not only are the male Crystallites difficult to distinguish from their sisters in outward appearance. In addition, Crystallite society differs from the Victorians in that it does not differentiate between 'masculine' and 'feminine' virtues. Instead, both sexes display traits which its Victorian narrator regards as traditionally feminine, such as submissiveness to a higher authority, a general lack of aggression, and, above all, a high degree of moral purity and chastity. Even the Crystallites' insistence on the impossibility of building new houses, and their dedication to the preservation of the existing ones reads like an extension of Ruskin's definition of femininity: the Crystallites

\footnotetext{
${ }^{10}$ For a brief overview of the debate up to the 1990 s, cf. LeMire.
} 
lack the male intellectual make-up that would allow them to be "doers" and "creators"; instead of dedicating their powers to "invention and creation", they have to content themselves with "sweet ordering" and preservation. ${ }^{11}$ (As if to provide a direct contrast, Morris' Nowhereans appear almost inordinately fond of building, taking obvious delight in tearing down the architectural remnants of the Victorian age and replacing them with lavishly decorated new ones.)

On the surface, their apparent lack of 'masculinity' is presented as a positive feature of the "mild-eyed men with downy, unrazored lips" (Hudson 248) that inhabit the world of the Crystal Age, and even the proudly 'masculine' narrator comes to acknowledge their superiority. On a superficial level, A Crystal Age seems to argue against the 'gendering' of certain character traits, and for the acquisition of positive characteristics across gender lines. ${ }^{12}$ Closer analysis, however, reveals the limits of this vision: while men have evidently acquired a range of positively connoted 'feminine' characteristics, there is no indication that Crystallite women are encouraged to develop 'masculine' features. Instead, most of the characteristics Victorian society would have regarded as 'masculine' (and hence arguably superior) have been rendered obsolete, thus severely limiting the possibilities of character development open to both sexes. There is no indication, however, that this is perceived as a drawback: as Battaglia observes, "to Hudson's mind and heart eutopia belongs to the other sphere, that is to a sphere that, being alternative to male values, may in comparison be defined as female" (145).

Crystallite society thus appears to reverse Victorian gender hierarchies by privileging femininity over masculinity - an attitude that ostensibly shows itself also in their veneration of the Mother. In this context, it becomes highly problematic that 'femininity' in the novel is consistently associated with a lower state of development. It is only the children of the house who display the androgynous characteristics described above; once a couple has passed into the higher state of parenthood, their gender characteristics diversify along traditional lines. ${ }^{13}$ The Father acquires not only a beard as an outward sign of his masculinity, but also the ability to rule over the family and to mete out justice to his children. The Mother of the House, who wears her hair longer than her daughters as an outward token of her femininity, not only develops a capacity for motherly love that exceeds that of all others, but also, it would seem from the example of Chastel, begins to display many of the negative qualities traditionally associated with women:

My very first glance revealed to me that she differed in appearance and expression from all other inmates of the house: [...] There was something wonderfully fascinating to me in that pale, suffering face, for, in spite of suffering, it was beautiful and loving; but dearer than all these things to my mind were the marks of passion it exhibited, the petulant, almost scornful mouth, and the half-eager, half-weary expression of the eyes, for these seemed rather to belong to that imperfect world from which I had been severed, and which was still dear to my unregenerate heart. (Hudson 175-6)

\footnotetext{
${ }^{11}$ cf. Ruskin, "Of Queen's Gardens" (qtd. in Parker, 13); Peter Morton also comments on the adrogynous appearance of the Crystallites (Science, 79).

${ }^{12}$ Similar arguments were brought forward by contemporary feminists e.g. Emily Davies (Parker, 3).

${ }^{13}$ This is in accordance also with Darwin's identification of women with a lower evolutionary state (Beer 200).
} 
It becomes evident from this passage that the full realisation of Chastel's femininity has separated her from the state of purity and perfection which characterises the other Crystallites, and has brought her closer to the imperfect (but more human) state Smith associates with the Victorian age. Moreover, it is also significant that Chastel, the Mother of the House and thus the only fully developed woman in the novel, is ravaged by a terminal illness which confines her to her room and limits her sphere of action, evoking the Victorian association between disease and the female body. In addition, her behaviour throughout many scenes suggests that she is suffering from hysteria (Battaglia 145), that typically female complaint of the Victorian period (Wood 163ff.), in addition to her physical malady. Moreover, Hudson's interpretation of Chastel's illness serves to re-enforce gendered medical discourses of the Victorian era, suggesting that her hysterical outbursts stem from the fact that her physical illness prevents her from fulfilling her 'natural' function of motherhood. ${ }^{14}$

Another problematic aspect emerges when one considers the close association between women and nature which characterises Crystallite attitudes towards the female sex: as has already been explained, a woman can only achieve a higher state of existence (in a social as well as evolutionary sense) through the fulfilment of her 'natural', biological function of motherhood. Moreover, the highest religious feast day of the Crystallites is the harvest festival, intended to honour both the bounty of nature and the fertility of the Mother - a correlation that has prompted Snodgrass to describe Chastel as an "isolated, somewhat pompous Gaea, or earth mother figure" (563). This association of femininity with nature, imperfection and/or a lower evolutionary state appears as an echo of Victorian theories on the subject. As such, it is highly problematic in a utopian novel which has been praised for its feminist credentials, and effectively invalidates any claims A Crystal Age might have had to a more enlightened stance towards gender. Rather than depicting a true matriarchy, as some critics have claimed, "[t]he utopian world of A Crystal Age is in fact the Victorian female world dominated by the Ruskinian ideal of the Mother of the House" (Battaglia 145).

Indeed, Hudson's picture of Chastel reads like an exaggeration of the Victorian ideology of the separate spheres: once a woman has been chosen to become Mother of the House, all other interests she might have had disappear; she is no longer required to participate in the work carried out by her former brothers and sisters, but spends a year in virtual seclusion acquiring the special knowledge reserved for Mothers. After this period, she moves into the Mother's Room, and her newly acquired official status is acknowledged by all members of the household, who pay homage to her and promise to love and serve her. From this point onwards, her entire life is geared towards the fulfilment of her biological function. In view of this consideration, it is difficult to understand why Snodgrass, in her analysis of the work, speaks of the "liberation of one woman per household" at the expense of "dooming the remaining females to celibacy" (564). While Chastel is, in fact, 'liberated' from the patriarchal authority of the Father of the House, she is subject to the constraints placed upon her by Crystallite society, and tormented by her preoccupation with fertility and the realisation that she will never

\footnotetext{
${ }^{14}$ Similar claims were advanced by opponents of the New Woman movement, who asserted that young women's diseases (bodily and mental) stemmed from their refusal to conform to accepted gender stereotypes (Wood 163).
} 
bear more than one child. The extent to which she herself defines her value in terms of her status and the number of children she has borne becomes strikingly apparent in her reaction to Smith's account of Victorian attitudes to women and motherhood:

"That all people should be equal, and all women wives and mothers seems to me a very disordered and a very repulsive idea. The one consolation in my pain, the one glory of my life could not exist in such a state as that, and my condition would be pitiable indeed...." (Hudson 196)

Moreover, Crystallite practice as experienced by the narrator diverges markedly from the matriarchal ideal proposed by Hudson. Due to Chastel's illness, her sphere of action is even more limited than Crystallite custom demands: she participates in the life of the household only through the intermediary of her children, who visit her room regularly and inform her of their everyday life. As a matter of fact, Smith never experiences the Crystallite system of matriarchal rule in action. In the only house he visits, all authority is concentrated in the person of the father: it is he who decides minor everyday matters, but also allots their respective tasks to all members of the household, and determines the appropriate punishment in cases of misdemeanour. Only the mother has the right to veto the father's decisions; what seems like an extension of women's privileges in comparison to the nineteenth century, however, turns out to be nothing but a confirmation of existing gender roles and stereotypes. While the father (the only obviously 'male' member of the family) metes out justice, the mother (the ultimate 'female' element) embodies mercy; a division which is entirely in keeping with Victorian notions. ${ }^{15}$

A similar discrepancy between theory and practice becomes evident in Hudson's depiction of women's work: the absolute equality which reigns between the androgynous children of the house initially encourages the assumption that there is no division of labour along gender lines in Crystallite society. However, this supposition is soon revealed to be erroneous: although women are not prevented from indulging in 'masculine' pursuits such as illustrating books and other branches of art (but not, it would seem, in rough outdoor activities such as ploughing fields and hewing wood), there are some occupations which are clearly regarded as exclusively feminine, such as teaching, nursing the sick, the preparation of the family's food, and all branches of needlework.

Moreover, it is interesting to observe that it is only these latter occupations and their results which the reader is allowed to witness through the eyes of the narrator: Smith comments favourably on the "succulent dishes" served by "picturesque handmaidens" (Hudson 53) who wait on the family (and whose status within the household is never explained), and frankly admires the beautiful clothes prepared by "the daughters of the house, whose province it is to make these things" (Hudson 68). Indeed, the majority of descriptions of women at work involve, in Smith's words, "some kind of wool-work" (Hudson 73) - the vagueness of his remark implying that the exact nature

\footnotetext{
${ }^{15} \mathrm{It}$ is interesting to note, moreover, that legal immunity is not a privilege reserved for the mother of the house alone; although this is nowhere explicitly stated in the book, it is obvious that the father, who, in the absence of codified legislation embodies justice, likewise stands above the law. There is no indication that the mother has the right to punish him for his transgressions (the assumption being that his higher moral state makes it impossible for him to commit any), just as she cannot sit court over her children in the manner of her husband.
} 
of their work is beyond his notice. In contrast, there is no description of women engaged in less traditionally feminine pursuits. The only partial exception is the account we receive of Yoletta's occupation as an illustrator; significantly, however, there is no favourable description of any of her drawings, but only of her trial and condemnation to thirty days' solitary confinement after she has spoiled a page and accidentally torn the book in a fit of pique.

In News from Nowhere, a similar tendency is observable: most women appear to be involved in that most traditional of feminine occupations, housework, and are said to be entirely happy with this state of affairs: "it is a great pleasure to a clever woman to manage a house skilfully" (Morris 94), Guest's Nowherean informant, old Hammond, asserts. In addition, he implies that women are by nature more suited to this type of work, invoking "an old Norwegian folk-lore tale called How the Man minded the House" (Morris 94) which ends in domestic disaster (Mineo 10). In addition, the only woman whom the reader encounters engaged in some other form of work is Philippa, the female master mason, who is noteworthy more for her antisocial behaviour than the beauty of her carvings (indeed, there is the suggestion that she overvalues the importance of her work). Moreover, in a society whose members are otherwise remarkable for their longevity and robust health, Philippa is reported to have only recently recovered from a severe and protracted illness. Like Hudson, Morris establishes a connection between illness and a lack of 'proper' femininity: while Chastel appears to suffer from hysteria because of her inability to fulfil her child-bearing duty, Philippa's illness is mentioned in connection with her 'unfeminine' occupation, and establishes a contrast to the healthy, beautiful women serving food at the guest hall.

While Morris does not go to the same lengths as Hudson in A Crystal Age as regards the importance of motherhood, it is made clear that child-bearing is assumed to be a vital part of women's lives: "How could it possibly be but that maternity should be highly honoured amongst us?", Hammond asks, going on to assert that all women possess an "instinct for maternity" (Morris 95) that is strengthened in a society which has done away with the "artificial burdens of motherhood" (Morris 94; italics in original). (One might even suggest Philippa's one redeeming feature is the existence of her beautiful and affable daughter, inserted probably to show that in Nowhere, child-bearing and a career are not mutually exclusive - and, more importantly, to assuage male readers' fears that women would leave off bearing children once they were given access to a greater range of professional opportunities.)

In the treatment of human relationships, however, Morris shows himself vastly superior to Hudson, who merely shelves the problem by envisaging a society in which sexuality is no longer an issue. Crucially, however, he fails to provide either a plausible explanation for this evolutionary step, or a means of making it palatable to the average contemporary reader, who is positioned so as to empathise with Smith's dilemma. In News from Nowhere, in contrast, the issue is addressed directly through the relationship between Clara and Dick, the crime of passion committed in the house Guest visits on his journey up the Thames, and lastly the strong attraction the narrator experiences for the enigmatic Ellen. The former two episodes serve to explain that Nowherean society, while not able to "get rid of all the trouble that besets the dealings between the sexes" (Morris 91), has at least ceased to be "commercial" or "artificially foolish" (Morris 92; 
italics in original) in its love matters, and to impose social sanctions on what (since the abolition of personal property) is essentially a private matter.

Morris proposes "eminently sensible" (Willmer xxxviii) solutions to matters of the heart which are clearly intended as comments on the Victorian status quo. ${ }^{16}$ The episode between Dick and Clara goes to show that Nowherean society is not only astonishingly liberal as regards divorce and remarriage, but also accepts that both men and women possess sexual appetites and a need for emotionally fulfilling relationships. In contrast to nineteenth-century views on the subject, Morris implies that sexuality is not a distinguishing factor between the genders, giving his Nowherean women the freedom of choice. The episode, however, leaves the reader in some doubt whether this permissive stance is actually a good thing: when Guest is introduced to Clara, he is told that she deserted Dick for another man, leaving their children in the care of one of his aunts. Since then, however, she has (under the guidance of Dick's uncle, old Hammond) realised the error of her ways and is now hoping to return to her former husband, who has not formed any new attachments in the meantime. The implication is, of course, that women are more fickle than men, but will return to their families once they have sown their wild oats and been made to see the error of their ways; it also shows, however, that the greater freedom Nowherean society affords women causes severe emotional stress for men (even though old Hammond maintains that Nowhereans "shake off these griefs in a way which perhaps the sentimentalists of other times would think contemptible and unheroic, but which we think necessary and manlike" [Morris 92]). ${ }^{17}$ Ellen's admission that she has "often troubled men's minds disastruously" (Morris 208) strikes a similar note, as does the episode of the crime of passion committed in the house they visit on their journey upstream. In the latter case, a love triangle between a woman and two men that has resulted in murder; in both instances, "the cause of the disturbance is imputed to the beauty and charm of women" (Mineo 13). If Morris' proposals do not appear entirely satisfactory, however, this is not only because they do not always seem to work in practice: on the one hand, the reader is left emotionally dissatisfied with solutions that presuppose a more rational attitude than is compatible with our own, less perfectly balanced psychological make-up. ${ }^{18}$ On the other hand, they do not conform to the reader's expectations of utopia, showing that Nowhere does not guarantee its inhabitants a state of perfect bliss, but merely a framework in which social and institutional obstacles to personal happiness have been removed.

It is in this respect that Morris most evidently engages in a dialogue with Hudson: in both novels, desire for a woman is equated with desire for utopia, and in both novels, this desire is ultimately denied.$^{19}$ A Crystal Age culminates in the narrator's realisation that Crystallite bliss is unattainable, and a final act of impatient despair that puts an end to his hopes at the very moment of their fulfilment. Morris's novel likewise acknowledges that utopia is not attainable for its nineteenth-century readership, but implies that - because biological evolution is presented as the result of political revolution

\footnotetext{
${ }^{16}$ For sustained discussion of this topic, cf. Mineo, "Eros Unbound".

${ }^{17}$ It is tempting to speculate that the episode is informed by Morris' own experience and - as it turned out, unfounded - hopes concerning his private life; a similar suggestion is put forward by Mineo (13).

${ }^{18}$ Cf. Clive Willmer's (xxxviii) criticism that Morris' proposals are not in accordance with Freudian psychology.

${ }^{19}$ For this point about News from Nowhere, cf. Marsh 23; Willmer xxxvii.
} 
rather than the opposite - it can be gained through patience and hard work (A.L. Morton 207). The reactions of the narrator's respective beloveds are indicative of the chances Victorian society - metonymically represented by Smith and Guest - has of achieving the ideal represented in the two novels: A Crystal Age ends with a scream of frustration; News from Nowhere with an encouraging look that promises the fulfilment of Guest's hopes at some point in the future. They also indicate, however, the chances their respective societies have of incorporating the disruptive element represented by the narrators.

As outlined above, both Hudson and Morris are caught up within an evolutionary paradigm that implies that living beings are subject to constant change, and are written during a period which subscribed to an ideology of technological progress, imperialist expansion, and a teleological conception of history. Obviously, all of these notions are starkly at odds with the essentially static nature of the traditional utopia: once perfection has ostensibly been attained, all further change becomes unnecessary, even undesirable. In the end, the success of the two novels depends not on the state of perfection achieved by the respective utopian societies, but - in keeping with the evolutionary paradigm - by their ability to adapt and respond to outside influences. In A Crystal Age, the narrator's love endangers the stability of Hudson's perfect society, and is therefore resisted by Yoletta until (too late) a means is found of incorporating into the Crystallite way of life. In contrast, Morris - instead of postulating an evolutionary stage at which humankind has, in one important respect, ceased to be truly human - shows that the problems caused by "dislocated erotic drives" (Mineo 12) can be absorbed by an otherwise harmonious and well-regulated society. If Morris's utopia, like the Crystal Age, is peopled by "a new species of human beings" (Mineo 8), it is a species that the reader can relate to and empathise with, and that can in turn learn to empathise with the narrator. However, Morris lays great emphasis on another problem that is present in both novels: having no interest in history, most utopians lack the background knowledge that would enable them to communicate effectively with the narrators and, more crucially, to avoid unwittingly repeating the mistakes of the past. A Crystal Age makes short shrift of the issue by insisting that several millennia of human evolution have made it constitutionally impossible for the Crystallites to relapse into nineteenth-century modes of thought. In News from Nowhere, in contrast, it is not Guest's love for Ellen but his sense of history and intimate knowledge of the past which exclude him from Nowhere; ${ }^{20}$ moreover, it also exposes one of its most important shortcomings. Significantly, however, Nowherean society shows itself open to criticism from within: while in A Crystal Age, the only voice that is occasionally critical of Crystallite society is that of the narrator, in News from Nowhere one of the most crucial impulses for further development - a heightened awareness of history - comes from Ellen herself.

From the point of view of the twenty-first century reader, both utopias fall short of perfection: like A Crystal Age, Morris's novel is frequently ambiguous and self-contradictory in its treatment of gender and sexuality as well as "dangerously antiintellectual [and] culpably blind to history" (Pinkney 53). More than a decade before Wells's Modern Utopia, however, it already takes into account the necessity of a utopia that is "not static but kinetic". The inclusion of Ellen shows that women and sexuality can be "productively disturbing", foreshadowing the possibility of the "leaner, more

\footnotetext{
${ }^{20}$ For sustained discussion of this point, cf. Hillgärtner, 128ff.
} 
challenging, more energetic, fully historicised and politicised world" (Pinkney 54) that may eventually evolve out of Morris's Nowhere. ${ }^{21}$ Pinkney's suggestion highlights two crucial features of the novel: in contrast to Hudson's vision, News from Nowhere depicts perfectability, not perfection; as such, it admits the possibility of improvement, and invites active participation on the reader's part in the imaginary task of envisaging its further development (Wilmer xxxv). Moreover, as the example of Ellen shows, the Nowhereans may yet come to develop the historical understanding that would enable them to relate to Guest not only in emotional, but in intellectual and political terms, and thus to fully integrate him (and the nineteenth-cenutry reader) into utopia.

Somewhat paradoxically, the main attraction of News from Nowhere thus lies in its evident flaws, much like Chastel's main attraction for Smith stems from her all too obvious weaknesses. Ultimately, Hudson's utopia fails because it does not act on the principle laid down in this scene: Crystallite society, it appears to insist, is indeed perfect. Thus it is entirely geared towards the preservation of the status quo: biological evolution has evidently reached its zenith; technological progress is regarded as harmful; and history appears to have come to a standstill. Hence, any change that can result from the (re)introduction of a disturbing element (be it historical knowledge or human sexuality) can only be for the worse. Just as the utter strangeness of the Crystallites leaves no room for empathetic involvement, their alleged perfection affords no scope for the reader's imagination. ${ }^{22}$ Moreover, the Crystallites' lack of flexibility precludes the establishment of the common ground which Smith so desperately seeks throughout the book, and prevents him from carving out a space for himself among them: unlike Guest, who proves a rich source of information to those Nowhereans who are interested in history, Smith has nothing to offer the Crystallites because they profit neither from his love nor from historical information.

If both novels thus feature narrators who have to return to the present partly because they are not yet ready for utopia, ${ }^{23}$ they also depict societies which are not (yet) ready for them. Ultimately, both novels suggest that utopia can only be attained through evolution and adaptation; Morris goes a crucial step beyond Hudson, however, when he shows that utopian visions succeed best when these processes work both ways, allowing narrators and readers to actively contribute to, rather than just passively admire, the imaginary societies they depict.

University of Vienna, Austria

\footnotetext{
${ }^{21}$ The subtitle also implies that the period Guest experiences is merely an "epoch of rest", an interlude between politically and socially more turbulent eras (A.L. Morton 206; Beaumont 183).

${ }^{22}$ As A.L. Morton notes, "[n]o one could imagine himself living, or could wish to live, in this Utopia any more than one could live in a stained glass window" (207).

${ }^{23}$ For this point about News from Nowhere, cf. Hillgärtner, 128.
} 


\section{WORKS CITED:}

Baccolini, Raffaella. “Woman.” In: Fortunati, Vita and Raymond Trousson. Dictionary of Literary Utopias. Dictionaires \& References. 5. Paris: Champion, 2000. pp. 699-705.

Baruch, Elaine Hoffman. "“A Natural and Necessary Monster': Women in Utopia.” In: Alternative Futures, 2:1 (1979). pp. 29-48.

Battaglia, B. "Crystal Age (A)." In: Fortunati, Vita and Raymond Trousson. Dictionary of Literary Utopias. Dictionaires \& References. 5. Paris: Champion, 2000. pp. 143-145.

Beaumont, Matthew. Utopia Ltd. Ideologies of Social Dreaming in England 1870-1900. Leiden; Boston: Brill, 2005.

Beer, Gillian. Darwin's Plots. $2^{\text {nd }}$ ed. Cambridge et al.: Cambridge University Press, 2000.

Boos, Florence S. and William Boos. "News from Nowhere and Victorian SocialistFeminism.” In: Nineteenth-Century Contexts, 14:1 (1990). pp. 3-32.

Domenicelli, Mario. "Love.” In: Fortunati, Vita and Raymond Trousson (eds). Dictionary of Literary Utopias. Dictionaires \& References. 5. Paris: Champion, 2000. pp. 367-72.

Fernando, Lloyd. "New Women” in the Late Victorian Novel. University Park; London: The Pennsylvania State University Press, 1977.

Ferns, Chris. Narrating Utopia: Ideology, Gender, Form in Utopian Studies. Liverpool Science Fiction Texts and Studies. 19. Liverpool: Liverpool UP, 1999.

Fortunati, Vita. "History." In: Fortunati, Vita and Raymond Trousson (eds). Dictionary of Literary Utopias. Dictionaires \& References. 5. Paris: Champion, 2000. pp. 286-92.

Fortunati, Vita and Raymond Trousson (eds). Dictionary of Literary Utopias. Dictionaires \& References. 5. Paris: Champion, 2000.

Kinna, Ruth. “The Relevance of Morris's Utopia.” In: European Legacy: Toward New Paradigm, 9:6 (Dec. 2004). pp. 739-50.

Hillgärtner, Rüdiger. "William Morris: ews from Nowhere; or, an Epoch of Rest: being some Chapters from a Utopian Romance (1890). “ In: Heuermann, Hartmund and Bernd-Peter Lange (eds). Die Utopia in der angloamerikanischen Literatur: Interpretationen. Düsseldorf: Bagel, 1984. pp. 120-38.

Holm, Jan. "The Old Grumbler At Runnymede." JWMS 10.2 (Spring 1993): 17-21.

Hudson, William Henry. A Crystal Age. New York: E.P. Dutto and Co., 1922.

Kumar, Krishan. Utopia and Anti-Utopia in Modern Times. Oxford: Basil Blackwell Ltd., 1987.

Lawton, Lesley. 'Lineaments of Ungratified Desire: William Morris's News from Nowhere as Utopian Romance." In: Anglophonia: French Journal of English Studies, 3 (1998). pp. 113-23.

Marsh, Jan. "Concerning Love: News from Nowhere and Gender." In: Coleman, Stephen and Paddy O'Sullivan (eds). William Morris \& News from Nowhere: A Vision for Our Time. Hartland: Green Books, 1990.

Marsh, Jan. “News from Nowhere as Erotic Dream.” JWMS 8.4 (Spring 1990): 19-23. 
Morris, William. News From Nowhere and Other Writings. Ed. Clive Wilmer. London: Penguin Books, 1998.

Morton, A.L. The English Utopia. Berlin: Seven Seas Publishers, 1968.

Morton, Peter. The Vital Science. Biology and the Literary Imagination 1860-1900. London: George Allen \& Unwin, 1984.

Morton, Peter. "Tracing a Theme in W.H. Hudson's A Crystal Age." In: English Language Notes, 25:4 (June 1988). pp. 61-65.

Parker, Christopher (ed.). Gender Roles and Sexuality in Victorian Literature. Aldershot: Scholar Press, 1995.

Partington, John S. "The Time Machine and A Modern Utopia: The Static and Kinetic Utopias of the Early H.G. Wells." In: Utopian Studies. Journal of the Society for Utopian Studies, 13:1 (2002). pp. 57-68.

Pfister, Manfred (ed.). Alternative Welten. München: Wilhelm Fink Verlag, 1982.

Sargent, Lyman Tower. "Women in utopia." In: Comparative Literature Studies 10 (1973). pp. 302-316.

Sedlak, Werner. "Utopia und Darwinismus." In: Pfister, Manfred (ed.). Alternative Welten. München: Wilhelm Fink Verlag, 1982. pp. 216-225.

Smyth, Clifford. "A Foreword." In: Hudson, William Henry. A Crystal Age. New York: E.P. Dutto and Co., 1922. pp. x-xix.

Snodgrass, Mary Ellen. Encyclopedia of utopian literature. Santa Barbara, Cal. et al.: ABC-CLIO, 1995.

Wells, H.G. A Modern Utopia. (1905) Eds Gregory Claeys and Patrick Parrinder. London: Penguin Books, 2005.

Wood, Jane. Passion and Pathology in Victorian Fiction. Oxford: Oxford University Press, 2001. 